Recepción: 14 / 05 / 2019

Aceptación: 28 / 06 / 2019

Publicación: 05 / 07 / 2019

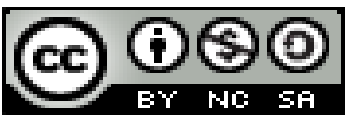

Ciencias de la educación

Artículo de investigación

\title{
Teachers' Perceptions on Inclusion at CENID - Technical University of Babahoyo
}

\author{
Percepciones de los docentes sobre la inclusión en el CENID - Universidad Técnica \\ de Babahoyo
}

\section{Percepção dos professores sobre a inclusão no CENID - Universidade Técnica de Babahoyo}

\author{
Mary Thalía Cifuentes-Rojas ${ }^{\mathrm{I}}$ \\ thali616@hotmail.com \\ Rina Rosalinda Castañeda-Junco II \\ reinaec@ hotmail.com \\ Julio Ernesto Mora-Aristega III \\ imora@utb.edu.ec
}

Correspondencia: thali616@ hotmail.com

I. Magíster en Gerencia de Innovaciones Educativas, Licenciada en Ciencias de la Educación Mención Idiomas (Inglés-Francés), Profesora de Segunda Enseñanza en Lenguas y Lingüística (Ingles -Francés), Docente de la Universidad Técnica de Babahoyo, Los Ríos, Ecuador.

II. Diploma Superior en Investigación de la Educación a Distancia, Licenciada en Ciencias de la Educación Mención Idiomas (Inglés-Francés), Profesora de Segunda Enseñanza en Lenguas y Lingüística (Ingles -Francés), Abogada de los Tribunales de la Republica, Docente de la Universidad Técnica de Babahoyo, Los Ríos, Ecuador.

III. Magíster en Administración de Empresas, Magíster en Docencia y Currículo, Magíster en Gestión de Recursos Humanos, Magíster en Contabilidad y Auditoría, Contador Público Auditor, Licenciado en Ciencias de la Educación Mención Educación Básica, Director del Centro de Idiomas de la Universidad Técnica de Babahoyo, Los Ríos, Ecuador. 


\begin{abstract}
Education is a fundamental human right and is the key to sustained development, peace and stability around the world. Inclusion of students with disabilities into regular classes is a serious concern nowadays. The purpose of this paper was to analyze the teacher's perceptions on inclusion at CENID - TECHNICAL UNIVERSITY OF BABAHOYO. The data was collected from a survey conducted to ten English teachers of the morning section at CENID - TECHNICAL UNIVERSITY OF BABAHOYO. A questionnaire with ten items set on a five-point Likert-type scale ranging from strongly agree to strongly disagree was used to analyze the teachers' perceptions on inclusion because it increases response rate and quality, and reduces the participants' frustration level. Procedures were identical for all participants. They were given and asked to complete the questionnaires in the English area. Most participants were in favor of inclusion, as $17 \%$ of them answered they strongly agreed with inclusion, $44 \%$ just agreed, $29 \%$ were neutral, only $6 \%$ disagreed, and $9 \%$ strongly disagreed. The teacher's perceptions on inclusion at CENID - TECHNICAL UNIVERSITY OF BABAHOYO show that this model is broadly accepted, as only $15 \%$ of participants disapproved of it.
\end{abstract}

Keys words: disability; IEP; included; inclusion; likert-type scale; perception.

\title{
Resumen
}

La educación es un derecho humano fundamental y es la clave para el desarrollo sostenido, la paz y la estabilidad en todo el mundo. La inclusión de estudiantes con discapacidades en las clases regulares es una preocupación seria en la actualidad. El propósito de este documento fue analizar las percepciones de los docentes sobre la inclusión en CENID - UNIVERSIDAD TÉCNICA DE BABAHOYO. Los datos se recopilaron de una encuesta realizada a diez profesores de inglés de la sección de la mañana en CENID - TECHNICAL UNIVERSITY OF BABAHOYO. Se utilizó un cuestionario con diez ítems establecidos en una escala tipo Likert de cinco puntos que va desde muy de acuerdo hasta muy en desacuerdo para analizar las percepciones de los maestros sobre la inclusión porque aumenta la tasa de respuesta y la calidad, y reduce el nivel de frustración de los participantes. Los procedimientos fueron idénticos para todos los participantes. Se les dio y se les pidió que completaran los cuestionarios en el área de inglés. La mayoría de los participantes estaban a favor de la inclusión, ya que el 17\% respondió que estaban totalmente de acuerdo con la inclusión, el 44\% estaba de acuerdo, el $29 \%$ era neutral, solo el $6 \%$ estaba en desacuerdo y el $9 \%$ estaba en desacuerdo. 
Las percepciones de los maestros sobre la inclusión en CENID - UNIVERSIDAD TÉCNICA DE BABAHOYO muestran que este modelo es ampliamente aceptado, ya que solo el $15 \%$ de los participantes lo rechazó.

Palabras claves: discapacidad; IEP; incluido; inclusión; escala tipo likert; percepción.

\section{Resumo}

A educação é um direito humano fundamental e é a chave para o desenvolvimento sustentado, a paz e a estabilidade em todo o mundo. A inclusão de alunos com deficiência em aulas regulares é uma preocupação séria hoje em dia. O objetivo deste artigo foi analisar as percepções do professor sobre a inclusão no CENID - UNIVERSIDADE TÉCNICA DE BABAHOYO. Os dados foram coletados de uma pesquisa realizada com dez professores de inglês da seção matutina do CENID UNIVERSIDADE TÉCNICA DE BABAHOYO. Um questionário com dez itens definidos em uma escala tipo Likert de cinco pontos variando de concordo fortemente a discordo totalmente foi usado para analisar as percepções dos professores sobre a inclusão porque aumenta a taxa de resposta e a qualidade e reduz o nível de frustração dos participantes. Os procedimentos foram idênticos para todos os participantes. Eles receberam e foram solicitados a preencher os questionários na área inglesa. A maioria dos participantes foi a favor da inclusão, pois $17 \%$ deles responderam que concordaram fortemente com a inclusão, 44\% apenas concordaram, 29\% eram neutros, apenas $6 \%$ discordaram e 9\% discordaram fortemente. As percepções do professor sobre a inclusão no CENID UNIVERSIDADE TÉCNICA DE BABAHOYO mostram que esse modelo é amplamente aceito, já que apenas $15 \%$ dos participantes o desaprovam.

Palavras chaves: deficiência; IEP; incluído; inclusão; escala do tipo likert; percepção.

\section{Introduction}

With the spread and development of English around the world, English is used as a second language in a country like India and for some people the 1st language. It enjoys a high prestige in the country. At present the role and status of English in India is higher than ever as evidenced by its position as a key subject of medium of instruction, curriculum. As the number of English learners is increasing different teaching methods have been implemented to test the effectiveness of the teaching process. Use of authentic materials in the form of films, radio, TV has been there for a long time. It is true that these technologies have proved successful in replacing the traditional teaching. The new era assign 
snew challenges and duties on the modern teacher. The tradition of English teaching has been drastically changed with the remarkable entry of technology. Technology provides so many options as making teaching interesting and also making teaching more productive in terms of improvements. At present the role and status of English is that it is the language of social context, political, socio cultural, business, education, industries, media, library, communication across borders, and key subject in curriculum and language of imparting education. It is also a crucial determinant for university entrance and processing well paid jobs in the commercial sector. Since there are more and more English learners in India, different teaching methods have been implemented to test the effectiveness of the teaching process.

multimedia in ELT in order to create English contexts. This helps students to get involved and learn according to their interests, It has been tested effectively and is widely accepted for teaching English in modern world. Technology is utilized for the upliftment of modern styles; it satisfies both visual and auditory senses of the students. With the spread and development of English around the world, English has been learned and used by more and more speakersDid you know that at the international level, inclusion is now considered a universal human right? Education is a fundamental human right and is the key to sustained development, peace and stability around the world. However, even in the 21 st century, many people remain excluded from basic education for disability reasons.

In our day-to-day experience, we discover that no two students are alike and that if we can detect the needs of each one, knowing the way in which it is easier for them to learn, our work is much more effective and satisfactory. This way of attending and responding to each student, this eagerness to respect diversity, considering it as a challenge of our classroom and not as a problem, complicates our life in the short term, but it is the one that gives meaning to this in the end. The educational model that we are going to present next, supposes the acceptance of a new conception of the education.

The inclusion of students with disabilities into regular classes is a serious concern nowadays, which is why the purpose of this paper was to analyze the teacher's perceptions on inclusion at CENID TECHNICAL UNIVERSITY OF BABAHOYO. Teachers' perceptions on inclusion are essential for education because they affect the way students deal with that significant process.

\section{Research question}


What are the English teacher's perceptions on inclusion at CENID - TECHNICAL UNIVERSITY OF

\section{BABAHOYO?}

\section{Research Plan}

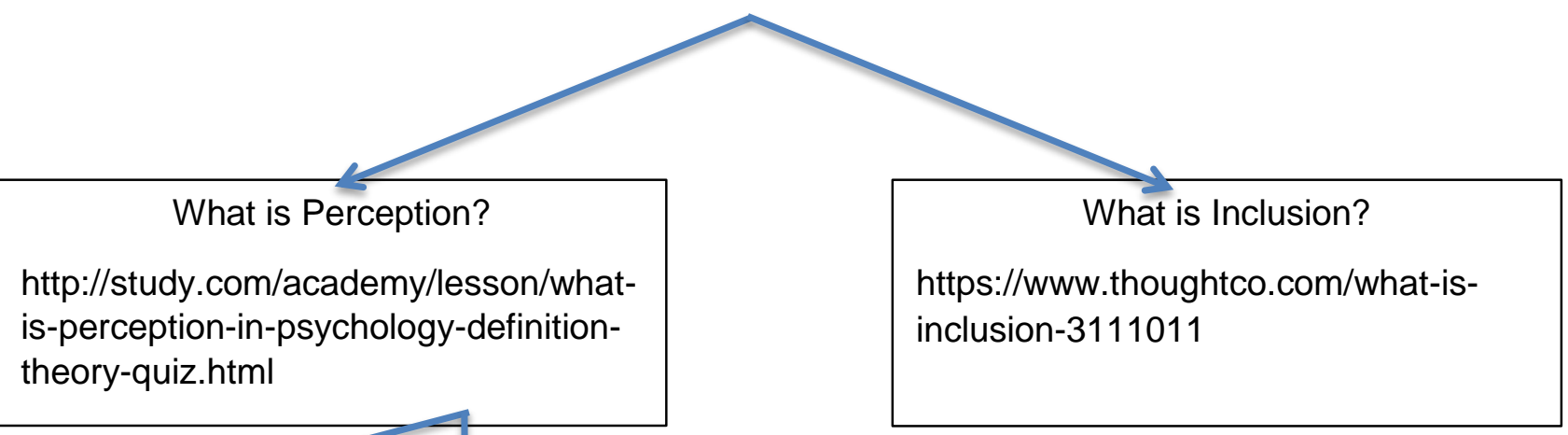

\section{Origen of Inclusion}

http://www.brighthubeducation.com/sp ecial-ed-inclusion-strategies/66803brief-legal-history-of-inclusion-inspecial-education/

\section{Advantages of Inclusion}

http://www.brighthubeducation.com/sp ecial-ed-inclusion-strategies/66128advantages-and-benefits-of-inclusion/
Disadvantages of Inclusion

https://mrwilsonspecialeducation.wordp ress.com/2010/04/07/inclusionadvantages-and-disadvantages/ 


\section{Literature Review}

\section{Definitions}

Perception is what we see, hear, smell, touch or taste through our senses. It is also the act of becoming aware through these senses, or the identification and interpretation of sensorial information. Perception helps us interact with the world around us. (Williams, 2003)

Inclusion is the act of teaching students with learning or any other types of disabilities in regular classrooms. There are two types of inclusion; Push in and full inclusion. (Webster, 2017)

One of the advantages of inclusion is that included students can be socially incorporated with their regular classmates. They can also make close friends who are going to work as models and help them develop the necessary skills to interact with all kinds of people in their future lives. (Perles, 2012)

One of the disadvantages of inclusion is that included students might feel unintelligent when they do not understand something their regular classmates do. Also, their regular classmates might get bored, having to be taught the same things once and again. (Wilson, 2010)

The origin of inclusion started in 1954, when a parents' movement, taking advantage that another movement was protesting against school exclusion because of race, protested for included education, yet, millions of students were excluded or did not receive appropriate services. In 1973, the Individuals with Disabilities

Education Act (IDEA) guaranteed educational rights for people with disabilities. But it was not until 1990 that real special education inclusion started. (Torreno, 2012)

\section{The key principles of inclusion are:}

Widening Participation, which guarantees that all students will be taken into account when asking and giving opinions. (Bauer, 2009)

Teacher Training so they can work in inclusive education classrooms.

Positive Attitudes towards Welcoming because it avoids segregation and provide quality education for included students.

Support Structures are human and material resources, which can impact on inclusion positively. 
Flexible Resourcing Systems allow included students free access to all facilities and provisions.

Inclusion-promoting Policies, which guarantees ethics preach and practice.

Inclusion-promoting Legislation, which states inclusion as a goal.

\section{Methods}

The data was collected from a survey conducted to ten English teachers of the morning section at CENID - TECHNICAL UNIVERSITY OF BABAHOYO.

The data was analyzed by putting the information and findings into a graph, in order to find out what the teachers' perceptions on inclusion at the previously mentioned high school were.

\section{Participants}

We selected ten English teachers of the morning section at CENID - TECHNICAL UNIVERSITY OF BABAHOYO, one male and nine females. Their ages ranged between twenty-five and sixty five years. Eight of them were Latinos and two were Americans. The participants didn't receive any type of incentive to take part in the research.

\section{Materials}

A questionnaire with ten items set on a five-point Likert-type scale ranging from strongly agree to strongly disagree was used to analyze the teachers' perceptions on inclusion because it increases response rate and quality, and reduces the participants' frustration level.

This paper presents a validated survey instrument by SurveyMonkey.

\section{Procedure}

The participants were informed about the research personally. Procedures were identical for all of them. They were given and asked to complete the questionnaires in the English area. They completed the questionnaires individually but they did so at the same time. 


\section{Results}

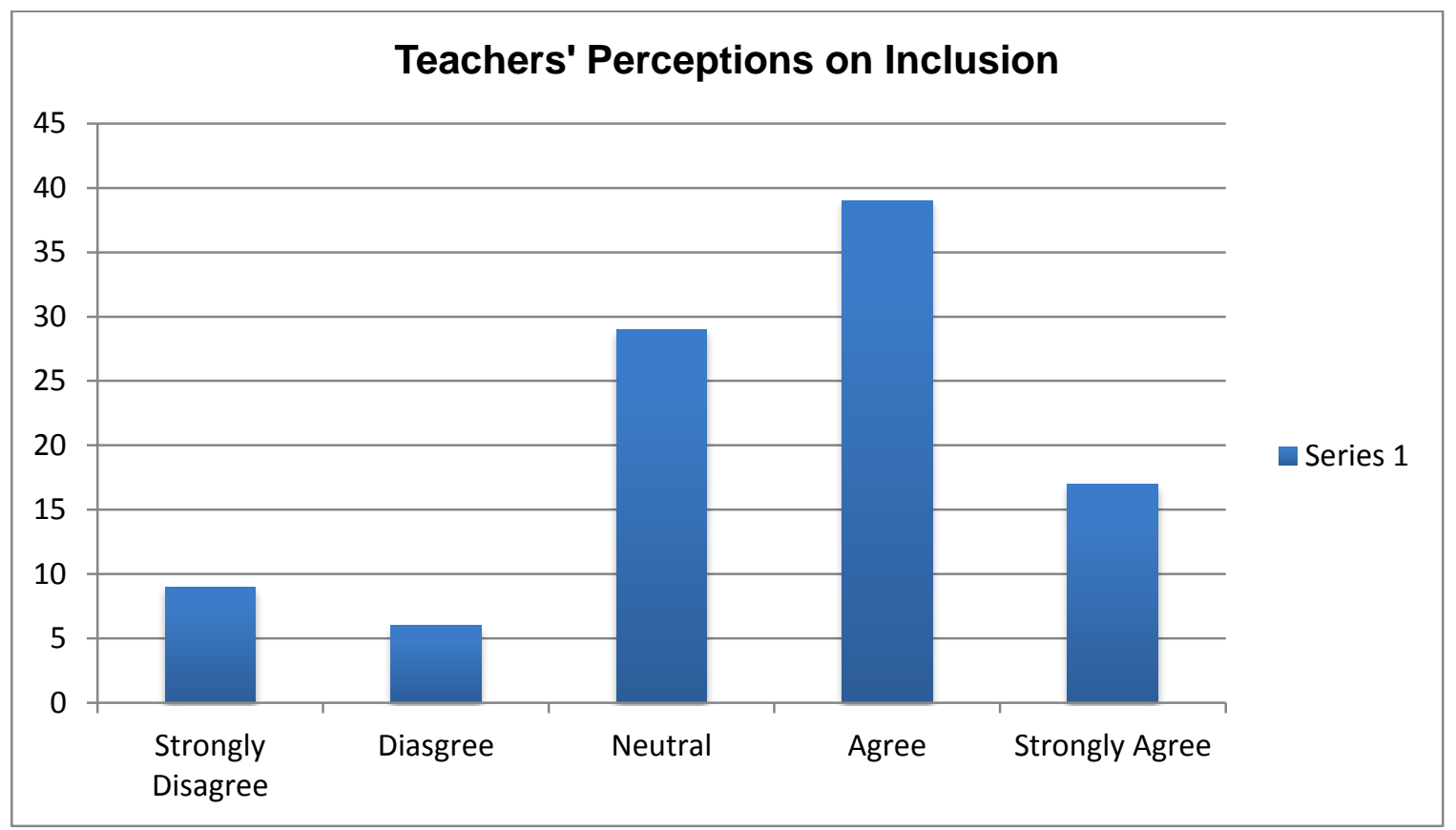

It is apparent from table 1 that most participants were in favor of inclusion, as $17 \%$ of them answered they strongly agreed with inclusion, $44 \%$ just agreed, $29 \%$ were neutral, only $6 \%$ disagreed, and 9 $\%$ strongly disagreed.

In question 1, "I believe inclusion benefits all students" $10 \%$ of the participants strongly disagreed, $20 \%$ disagreed, $30 \%$ were neutral, $20 \%$ agreed and $20 \%$ strongly agreed.

In question 2, "I collaborate with the special education teacher to plan lessons" $20 \%$ of the participants strongly disagreed, nobody disagreed, $50 \%$ were neutral, $20 \%$ agreed and $10 \%$ strongly agreed.

In question 3, "I am confident in my ability to differentiate instruction for all leaners in my classroom" none of the participants strongly disagreed, nobody disagreed, $40 \%$ were neutral, $60 \%$ agreed and nobody strongly agreed.

In question 4, "I believe there are some special education students who should not be in the general education setting" none of the participants strongly disagreed, 10\% disagreed, nobody was neutral, $70 \%$ agreed and $20 \%$ strongly agreed. 
In question 5, "I am actively involved in the development of the IEP's of students in my classroom" $10 \%$ of the participants strongly disagreed, $20 \%$ disagreed, $30 \%$ were neutral, $20 \%$ agreed and $20 \%$ strongly agreed.

In question 6, "I view the special education teacher as my partner in the classroom" $20 \%$ of the participants strongly disagreed, nobody disagreed, $30 \%$ were neutral, $40 \%$ agreed and $10 \%$ strongly agreed.

In question 7 , "I provide most of the instruction (70\% or greater) in my classroom" none of the participants strongly disagreed, nobody disagreed, $10 \%$ were neutral, $80 \%$ agreed and $10 \%$ strongly agreed.

In question 8, "I believe it is best to group students based on ability within the classroom" $10 \%$ of the participants strongly disagreed, nobody disagreed, $30 \%$ were neutral, $40 \%$ agreed and $20 \%$ strongly agreed.

In question 9, “The special education teacher is primarily responsible for the students with IEP's in the inclusion classroom" $20 \%$ of the participants strongly disagreed, $10 \%$ disagreed, $30 \%$ were neutral, $30 \%$ agreed and $10 \%$ strongly agreed.

In question 10, "I have high expectations for all students in my classroom" none of the participants strongly disagreed, nobody disagreed, $40 \%$ were neutral, 10\% agreed and 50\% strongly agreed.

\section{Discussion}

Findings in the present study are consistent with the findings of Kristen Robertson, (Robertson, 2003), which hold favorable perceptions on inclusion of students in regular classrooms. This study aimed to analyze English teachers' perceptions and the way they affect how students deal with that significant process. The results of this study indicate that general education teachers hold favorable perceptions of educating students with an IEP in an inclusive classroom.

\section{Conclusion}

Teachers' perceptions on inclusion are essential for education because they affect the way students deal with that significant process. The English teacher's perceptions on inclusion at CENID TECHNICAL UNIVERSITY OF BABAHOYO show that this model is broadly accepted, as only 
$15 \%$ of participants disapproved of it. This might be because inclusion is generally considered to be an educational human right, and is the key to sustained development, peace and stability around the world. Fortunately, inclusion has been highly accepted in our society, which is going to favor that valuable part of the population that formerly was completely unattended.

\section{Recommendations}

Further research should be conducted by applying the questionnaires to many more people, so the results are more reliable. What was challenging being to find a validated survey instrument, so it would be advisable to provide one.

\section{Bibliography}

Bauer, L. (2009). Retrieved 2017, from https://www.european-agency.org/sites/default/files/keyprinciples-for-promoting-quality-in-inclusive-education_key-principles-EN.pdf

Perles, K. (2012). Retrieved 2017, from http://www.brighthubeducation.com/special-ed-inclusionstrategies/66128-advantages-and-benefits-of-inclusion/

$\begin{array}{lllll}\text { Robertson, } & \text { K. } & \text { (2003). } & \text { Retrieved }\end{array}$ https://link.springer.com/article/10.1023/A\%3A1022979108096

Torreno, S. (2012). Retrieved 2017, from http://www.brighthubeducation.com/special-ed-inclusionstrategies/66803-brief-legal-history-of-inclusion-in-special-education/

Webster, J. (2017). Retrieved 2017, from https://www.thoughtco.com/what-is-inclusion-3111011

Williams, Y. (2003). Retrieved 2017, from http://study.com/academy/lesson/what-is-perception-inpsychology-definition-theory-quiz.html

$\begin{array}{lllll}\text { Wilson, } & \text { M. } & \text { (2010). } & \text { Retrieved } & \text { 2017, }\end{array}$ https://mrwilsonspecialeducation.wordpress.com/2010/04/07/inclusion-advantages-anddisadvantages/ 
Teacher's Perceptions on Inclusion at Cenid- Technical University of Babahoyo

\begin{tabular}{|c|c|c|c|c|c|}
\hline Questions & $\begin{array}{l}\text { Strongly } \\
\text { Disagree }\end{array}$ & Disagree & Neutral & Agree & $\begin{array}{l}\text { Strongly } \\
\text { Agree }\end{array}$ \\
\hline $\begin{array}{l}\text { I believe inclusion benefits all } \\
\text { students }\end{array}$ & 1 & 2 & 3 & 2 & 2 \\
\hline $\begin{array}{l}\text { I collaborate with the special } \\
\text { education teacher to plan lessons }\end{array}$ & 2 & 0 & 5 & 2 & 1 \\
\hline $\begin{array}{l}\text { I am confident in my ability to } \\
\text { differentiate instruction for all } \\
\text { leaners in my classroom }\end{array}$ & 0 & 0 & 4 & 6 & 0 \\
\hline $\begin{array}{l}\text { I believe there are some special } \\
\text { education students who should } \\
\text { not be in the general education } \\
\text { setting }\end{array}$ & 0 & 1 & 0 & 7 & 2 \\
\hline $\begin{array}{l}\text { I am actively involved in the } \\
\text { development of the IEP's of } \\
\text { students in my classroom }\end{array}$ & 1 & 2 & 3 & 2 & 2 \\
\hline $\begin{array}{l}\text { I view the special education } \\
\text { teacher as my partner in the } \\
\text { classroom }\end{array}$ & 2 & 0 & 3 & 4 & 1 \\
\hline $\begin{array}{l}\text { I provide most of the instruction } \\
\text { ( } 70 \% \text { or greater) in my classroom }\end{array}$ & 0 & 0 & 1 & 8 & 1 \\
\hline $\begin{array}{l}\text { I believe it is best to group } \\
\text { students based on ability within } \\
\text { the classroom }\end{array}$ & 1 & 0 & 3 & 4 & 2 \\
\hline $\begin{array}{l}\text { The special education teacher is } \\
\text { primarily responsible for the } \\
\text { students with IEP's in the } \\
\text { inclusion classroom }\end{array}$ & 2 & 1 & 3 & 3 & 1 \\
\hline \multirow[t]{2}{*}{$\begin{array}{l}\text { I have high expectations for all } \\
\text { students in my classroom }\end{array}$} & 0 & 0 & 4 & 1 & 5 \\
\hline & $9 \%$ & $6 \%$ & $29 \%$ & $39 \%$ & $17 \%$ \\
\hline
\end{tabular}

